doi: $10.19090 /$ i.2018.29.7-21

UDC: 251

ISTRAŽIVANJA

JOURNAL OF HISTORICAL RESEARCHES

29 (2018)
ORIGINAL SCIENTIFIC PAPER

Received: 16 June 2018

Accepted: 14 November 2018

\author{
NENAD MARKOVIĆ \\ Charles University Prague \\ Czech Institute of Egyptology \\ nenadmarkovic.is@gmail.com
}

\title{
THE CURIOUS CASE OF HERESANKH, A PERFECT PLAYER OF THE SISTRUM OF MIN AND A PRIESTESS OF THE KING'S SISTER PHILOTERA
}

\begin{abstract}
The present paper aims to resolve problems around the identification of Heresankh, a perfect player of the sistrum of Min and a priestess of the king's sister Philotera, and to propose her position within the powerful family of high priests of Memphis during the Ptolemaic rule. The study reveals that she most likely belonged to the secondary branch of the same family, both lines having the joint ancestor in the priest Anemhor, who was in fact the father of Nesisti-Pedubast, the earliest known high priest of Ptah under the Hellenistic Dynasty. She most likely lived between 249 BC and $183 \mathrm{BC}$. The marriage union of her related parents, Neferibre and Herankh, must have influenced her social standing at Memphis since Heresankh is the only known priestess of the most important sanctuaries within the Memphite necropolis, namely the Sarapieion, the Osirion of Rutiset and the Anoubieion, all located at Saqqara and Abusir.
\end{abstract}

Keywords: Ptolemaic Egypt, indigenous elite, high priests of Ptah, Memphis, women's history, priesthood.

\begin{abstract}
A perfect player of the sistrum of Min and a priestess of the king's sister Philotera, Heresankh, ${ }^{1}$ is known according to two monuments from the Memphite necropolis at Saqqara: the funerary stela London BM EA 389 and the standing statue Louvre N $2456=$ IM $6165 .{ }^{2}$ Her parents were Neferibre, ${ }^{3}$ who is named only on a statue, and Herankh, ${ }^{4}$ whose name is present on both monuments. Her mother is called 'mistress of the house $(n b . t p r){ }^{\prime}, 5$ while her father is designated only as god's servant ( $\left.h m-n t r r\right)$, the highest
\end{abstract}

${ }^{1}$ PP III 5524.

${ }^{2}$ Both monuments are republished most recently by Panov 2017a: 387-389 (with older literature).

${ }^{3}$ PP III 5646.

${ }^{4}$ Mentioned in PP III 5645.

${ }^{5}$ The present author is starting a project on royal and non-royal elite women in Lower Egypt. The project is funded by the Stiftungsfonds für Postgraduates der Ägyptologie (Vienna). 
ranking sacerdotal position within ancient Egyptian temple. ${ }^{6}$ A text on the stela London BM EA 389 testifies about her funeral in year 22 of an unnamed Ptolemaic king and that funerary rites were conducted by her son called Nesisti. ${ }^{7}$ Heresankh died when she was at the age of 66 years, 5 months and 5 days. Unfortunately, the burial place of Heresankh is presently unknown, but was certainly located somewhere in the vast necropolis of Saqqara, possibly in the area of the Sarapieion, or even further north near Abusir. ${ }^{8}$ The burial date was used as a starting point to calculate her year of birth and to chronologically position her family within the Memphite society during the Ptolemaic era. According to a modern consensus, a year 22 is believed to correspond to year 22 of Ptolemy II, ${ }^{9}$ meaning that Heresankh could have been born around $330 \mathrm{BC}$ and died in $263 \mathrm{BC}$. Later, another dating was proposed,to year 22 of Ptolemy III (226/225 BC), ${ }^{10}$ but have been somewhat neglected in modern historiography. ${ }^{11}$ In fact, the choice between Ptolemy II or Ptolemy III is only based on the career of the only other known priest of Philotera at the time, Nesisti-Pedubast, the earliest known Ptolemaic high priest of Memphis himself, and assumption that he served in the cult of Philotera before or after Heresankh. Both chronologies position Heresankh in the late fourth to theearly third centuries $\mathrm{BC}$, which now seems to be highly improbable scenario, especially since another known priest of Philotera needs to be taken into account, ${ }^{12}$ together with stylistic similarities and differences between numerous studied monuments (such as layout and material, depictions and decoration, dimensions), text composition, palaeography, and prosopographical data.

Nevertheless, not all researchers agreed with $H$. de Muelenaere's dating of Heresankh's monuments. Already P. Munro proposed different dating of her stela to 'around 183 BC', i.e. year 22 of Ptolemy V, ${ }^{13}$ while M. Panov most recently successfully defended Munro'sdating by comparing her stela to the funerary stelae London BM EA 391 of Horemakhet, high priest of Memphis under Ptolemy III, Ptolemy IV, and Ptolemy V, ${ }^{14}$ and Bologna 1943 of Ahmose, high priest of Letopolis, ${ }^{15}$ who died and was buried in year 22 of Ptolemy V. ${ }^{16}$ Both stelae exhibit the same layout and used material (round-topped, limestone), similar dimensions (London BM EA 389: $53 \mathrm{~cm}$ x $34.5 \mathrm{~cm}$; London BM EA 391: $61 \mathrm{~cm}$ x $38 \mathrm{~cm}$; Bologna 1943: $52 \mathrm{~cm} \mathrm{x} 32 \mathrm{~cm}$ ), and uniform depictions and decorations (winged sun-disc with pendent uraei is at the top, while beneath is a scene of the deceased

${ }^{6}$ cf. De Meulenaere 1982: 1097.

${ }^{7}$ PP IX 5535a.

${ }^{8} \mathrm{cf}$. Ray 1999: 692-693. The potential discovery of the tomb-complexes of the Ptolemaic high priest of Memphis and their relatives require much more textual and archaeological investigation.

${ }^{9}$ cf. De Meulenaere 1959: 245; Quaegebeur 1971: 246; Gorre 2009: 222-223.

${ }^{10} \mathrm{cf}$. Thompson $1988^{1}: 128$.

${ }^{11}$ Most recently, D.J. Thompson (2012²: 119, 122 n. 119) concluded that 'a separate priestess [of Philotera] was named, Harsynchis [Heresankh], daughter of Nepherpres [Neferibre], from another, or perhaps related, Memphite priestly family', adding that she 'may be granddaughter of Esisout I-Petobastis I [Nesisti-Pedubast]' Her choice is still Heresankh as the successor of Nesisti-Pedubast.

${ }^{12}$ Already mentioned in Carney 2013: 176 n. 153.

${ }^{13}$ Munro 1973: 166, 340.

${ }^{14}$ PP III 5358

${ }^{15}$ PP IX 5351; cf. Otto 1956: 109; Panov 2017a: 261-290.

${ }^{16}$ Panov 2017a: 387-388. 
presenting libations to the enthroned figure of the god Osiris with an offering-table in between; below are lines of hieroglyphic text, composed in similar way) as the stela of Heresankh. This correspondence further indicates that Heresankh could have lived between $249 \mathrm{BC}$ and $183 \mathrm{BC}$. Historical implications of this alternative dating have never been discussed in modern historiography. This paper aims to resolve current dating issues regarding Heresankh and propose her placement within a secondary branch of the family of Ptolemaic high priest of Ptah united with a main branch by a marriage.

\section{The cult of Philotera and Heresankh}

The first chronological clue is the cult of Philotera, the deceased sister of Ptolemy II and Arsinoe II. ${ }^{17}$ Heresankh is the only known priestess of the cult of Philotera. In fact, the only two other known priests of Philotera in Egypt belong to the family of the high priests of Ptah. The first one is Nesisti-Pedubast, the earliest known high priest of Ptah under the Ptolemies, ${ }^{18}$ who was promoted during the reign of Ptolemy II and was dead likely by year 37 of the same ruler (248 BC). ${ }^{19}$ Another one is also called Nesisti, who was the son of high priest Horemakhet and his wife Nefertiti, himself being in all likelihood his father's successor as the highest priest of Memphis in the early second century BC and served probably under Ptolemy V and Ptolemy VI. ${ }^{20} \mathrm{He}$ was the priest of both Arsinoe II and Philotera mentioned together (god's servant of the Goddesses of Two Lands Arsinoe and Philotera, hm-ntr ntrtjnwt3wjJrsn3t Pjldr3t), ${ }^{21}$ which is in accordance with Greek literary tradition where a reference to the worship of both sisters together is preserved. ${ }^{22}$ Similarly, priests of Arsinoe IIare attested in the family of high priest of Ptah for the first four generations: it seems that after the death of high priest Nesisti, the son of high priest Horemakhet, sometimes after 183 $\mathrm{BC}$, this title was apparently transferred to Heru III (174-131 BC), high priest of Letopolis certainly sometimes after the deaths of his father, high priest Heru II, in 164 BC and probable brother, high priest Psamtik, before $131 \mathrm{BC},{ }^{23}$ probably related by marriage to the family of

\footnotetext{
${ }^{17}$ For Philotera, see Pfeiffer 1922: 14-37; Macurdy 1932: 127-128; Troy 1986: 179; Carney 2013: 98.

${ }^{18}$ PP III 5361 = PP III 5862 = PP III 5364 = PP III 5370; cf. Gorre 2009: 285-296; Panov 2017a: 101-108.

${ }^{19}$ cf. Quaegebeur 1971: 246; Collombert 2008: 96-97; Gorre 2009: 293-294; Thompson 2012²: 119.

${ }^{20}$ PP III 5363. However, it should be noted that J. Quaegebeur (1980: 68) identifiedNesistias his probable brother Pasherienptah I, referring to him se Nesisti-Pasherienptah, yet without any conclusive evidence. For the discussion of the career of Nesisti, see most recently Panov 2017b: 45-47.

${ }^{21}$ cf. Panov 2017b: 43-49.

22 cf. Carney 2013: 176 n. 153.

${ }^{23}$ PP IX 5359a. Most recently, M. Panov (2017b: 47) is arguing that the high priest of Letopolis, Ahmose, the owner of the Bologna stela and a number of other monuments (see Panov 2017a: 261-286), himself being the grandfather of high priest Heru III, was involved in the cult of Arsinoe II during his lifetime. This is only partially correct, since Ahmose is designated only in the administrative capacity as a scribe of Ptah and Arsinoe, goddess, who is loving brother (š̌ $n$ Pth h̆ $n^{\complement} J r s n 3 t n t r t ~ m r . t-s n$ ) on a statue Strasbourg 1381 (Panov 2017a: 263-264) and a statue-base Louvre E 3036 (Panov 2017a: 270, 272), both from the Sarapieion at North Saqqara, but not as a god's servant of Arsinoe. Neither Ahmose's son Heru II (PP IX 5359) nor Heru II's elder son Psamtik (PP IX 5374 = PP IX 5877) were priests of Arsinoe II, only the titles of scribes of Ptah and Arsinoe are given. Ahmose's grandson Heru III is designated specifically as a god's servant of Isis and Arsinoe of the Arsinoeion ( $h m-n \underline{t} r$ 3stn.mJrsn3tprJrsn3t) on his funerary stela Louvre C124 (Panov 2017a: 302, 303). The next priest of Arsinoe II in the family of high priests of Ptah was Pedubast III (PP III 5371), who lived between 121 BC and 76 BC.
} 
high priest Nesisti. ${ }^{24}$

The main question that arise from this reconstruction is whether Heresankh was the leader of the cult of Philotera before or after the appointment of Nesisti-Pedubast. Firstly, the death of Heresankh in $263 \mathrm{BC}$ seems to match perfectly commonly accepted date of the appointment of Nesisti-Pedubast as a high priest of Memphis in 263/262 BC. ${ }^{25}$ Thompson also comments that the apomoira, or "portion" tax, was assigned for the cult of Arsinoe II to be maintained in each temple in regnal year 23 of Ptolemy II (263 BC) and connects it to the appointment of new high priest. ${ }^{26}$ If so, Nesisti-Pedubast would have succeeded Heresankh as leader of the cult of Philotera. The main objections to this scenario are (1) the date of Nesisti-Pedubast's promotion as a high priest of Ptah, (2) his social status at Memphis before he was appointed to the highest priesthood, (3) his close cooperation with Ptolemy II and his court, and (4) temporal uncertainty of the introduction of the cult of Philotera in traditional temples and clear intention that two sisters need to be worshiped together, at least initially.

His funerary stela, London BM EA $379,{ }^{27}$ documents that, among many positions he received from the Ptolemaic king, Nesisti-Pedubastwas appointed as the priest in the cults of both royal sisters, Philotera and Arsinoe II respectively, commemorating the introduction of the royal cult in Memphis. When exactly Philotera died and was deified are uncertain at present, ${ }^{28}$ but she certainly predeceased her well-known sister Arsinoe II, ${ }^{29}$ who may have died in 268 BC. ${ }^{30}$ Since the mortuary cult of Arsinoe II started to appear outside Alexandria only after year 20 of Ptolemy II (266/265 BC), ${ }^{31}$ it seems more likely that Nesisti-Pedubast was a rather perfect candidate for the first priest of bothking's deified sisters, which again perfectly corresponds to Greek literary tradition and his personal promotion by Ptolemy II as the highest-ranking official in the ancient capital of Egypt and the centre of traditional kingship and culture. ${ }^{32}$ Since only three indigenous individuals are known to be officiating the cult of Philotera in Egypt, two of them together with her sister Arsinoe II, it is highly probable that her cult was introduced to the indigenous temples together with the cult of Arsinoe II, making Nesisti-Pedubast her initial priest and Heresankh his successor. Otherwise, after the death of Nesisti/Pedubast sometimes before $248 \mathrm{BC}$, the cult of Philotera would completely disappear from surviving records, only to be revived in the first half of the second century BC under his great-grandson Nesisti, three generations afterwards. Nesisti-Pedubast's successors as high priests of Memphis, Anemhor II and his son Horemakhet, were only known as the priests of Arsinoe II. ${ }^{33}$ Previous scenario would

\footnotetext{
${ }^{24}$ Thompson 2012 $: 122$ n. 121 states that priests of Arsinoe II are Ahmose, Heru II and Psamtik, which is incorrect.

${ }^{25}$ Maystre 1992: 180; Thompson 2012²: 119.

${ }^{26}$ Thompson 2012²: 119 n. 117. See also Manning 2003: 56-57.

${ }^{27}$ Panov 2017a: 101-102, 106.

${ }^{28}$ There is a possibility that a temple erected in honour of an unnamed sister of Ptolemy II ( $m r . t$ sn.t), mentioned in the Pithom Stele (Cairo CG 22183), apparently in connection with events of year 16 (270/69 BC), was a temple to Philotera; cf. Naville 1902: 73; for another interpretation, see Grzybek 1990: 74.

${ }^{29}$ Macurdy 1932: 127.

${ }^{30}$ cf. van Oppen 2010: 150.

${ }^{31}$ Thiers 1999: 432-445; Thiers 2007: 178-180; Collombert 2008: 83-99.

32 cf. Thompson 2012²: 99-143.

${ }^{33}$ cf. Panov 2017a: 133, 134.
} 
make unnecessary chronological gap in title holders, which could be successfully filled with the career of Heresankh as the priestess of Philotera. It is therefore plausible that the title returned to the main family branch of high priests of Ptah after Heresankh's death in 183 $\mathrm{BC}$, when a high priest Nesisti, son of Horemakhet, succeeded the position from her and reunited the cult of Philotera with the cult of Arsinoe II.

\section{The formal careers of Heresankh and Nesisti-Pedubast}

Nesisti-Pedubast claims da he was chosen by the king among others in Memphis to fill the city's highest religious position, which seems to disappear from the records after the reign of the Persian king Xerxes I (486-465 BC). ${ }^{34}$ He was probably well in his 40s when he was chosen as high priest of Memphis and priest of the dynastic cult by Ptolemy II. ${ }^{35}$ Although his funerary stela London BM EA 379 lacks clear internal dating except the mention of 23 years of his office in Memphis ( $m$ rnp 23.t) in line 2 of the main text, ${ }^{36}$ the sequence of numerous titles he had received from the Ptolemaic king specified in lines 3, 4 and 5 was certainly arranged according to their significance in administrative and cultic organization and unveils his supremesocio-political status at Memphis at the time: great [governor] of Memphis ([h3tj$\left.p^{\ulcorner} t\right] w r m$ 'Inb- $\left.H \underline{d}\right),{ }^{37}$ god's servant of the king's daughter, the king's sister Philotera ( $h m-n \underline{t} \underline{n} n$ s3.t nsw sn.t nswPjjlwtr3), god's servant of the king's daughter, the king's sister, the king's wife, the daughter of Amon-Re, master of the Two lands, Arsinoe, the goddess who loves brother, beloved of Isis, the mother of Apis (hm-ntr $n$ s3.t nsw sn.t nsw hm.t nsw s3.t Imn-R ${ }^{c}$ nbt3.wjIrsjn3t ntr.t mr.t-snmrj 3s.t mw.t Hp), master of the secrets in the house of Ptah as chosen

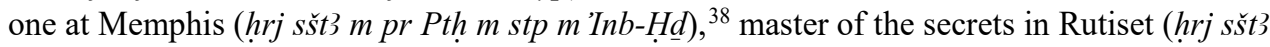
$m R w . t-j s w t),{ }^{39}$ chief director of craftsmen (wr hrp h hmw.t). ${ }^{40}$ His 23 years of office most likely preceded his appointment as high priest, especially since the preserved text on his funerary stela starts with outspoken statement that 'there were not found my faults since I governed Memphis during 23 years as chosen of king himself and his entourage ( $n n g m j w n=j \underline{d} r \mathrm{~h} r p=j$

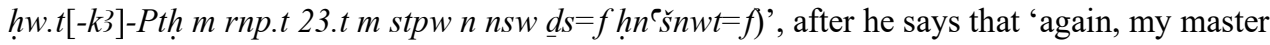
favoured me (jw whm $n n b=j h s w w j)$ ', before he started to list all the titles he received from the unknown king. Bestowed titles and favours could be therefore interpreted as the reward for his good administration at Memphis, dating back to the reign of Ptolemy I. ${ }^{41}$ Indeed, the

\footnotetext{
${ }^{34} \mathrm{cf}$. Vittmann 2009: 89-91.

${ }^{35}$ One of his numerous sons, Anemhor II (PP III 5352 = PP III 5442 = PP IX 5442a), was born in 289 BC, while he also had one elder son, Pedubast I (PP IX 5370), who was very likely his immediate successor.

${ }^{36}$ cf. Gorre 2009: 293-295; Panov 2017a: 102 n, 131; contra in Collombert 2008: 96-97.

${ }^{37}$ Reading is according Gorre 2009: 290, 294, 456-459. On the other hand, M. Panov (2017a: 103 n. 133) choose

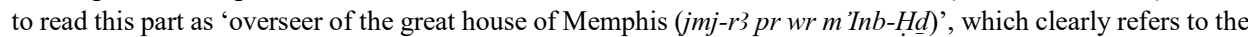
royal palace. However, both readings are pure speculations since this part of the stela is missing and large lacuna occupies the space before Gardiner signA19, 'great (wr)'.

${ }^{38}$ Translation is according Panov 2017a: 103.

${ }^{39} \mathrm{cf}$. Devauchelle 1998: 598-600; Devauchelle 2010: 49-50.

${ }^{40}$ cf. Maystre 1992: 4-13; Devauchelle 1992: 205-207; Klotz 2014: 722-723.

${ }^{41} \mathrm{cf}$. Gorre 2009: 294. However, G. Gorre thinks that he was bestowed favours in return for his reconstruction of the Memphite temples. This is based on a suggestion, first made by E. A. E, Reymond (1980: 62), that in a clear break in line 2 should be written 'I governed [work in the house of] Ptah ( $h r p=j[k 3 t m p r-] P t h)$ '. However, after
} 
appointment of Nesisti-Pedubast should be linked to the royal decree preserved on the socalled Sais stela, that summoned governors, local headmen, god's servants and divine fathers of the temples of Upper and Lower Egypt to Alexandria in year 20 of Ptolemy II (266/265 BC) to establish the cult of Arsinoe II across the country. ${ }^{42}$

On her funerary stela, Heresankh is designated only as a perfect sistrum player of Min (jhjj.t nfr.t n.t Mnw), but a text on her statue reveals priestly positions within the Sarapieion, the Osirion of Rutiset and the Anoubieion, all located at Saqqara and Abusir. ${ }^{43}$ On the Louvre statue, she is designated as 'a perfect sistrum player of Min, lord of Senut, female god's servant of Isis and Nephthys, of house of Osiris-Apis, of house of Osiris at Rutiset and of house of Anubis who is on his hill, female god's servant of king's daughter Philotera (jhjjt nfr.t n.t Mnw $n b$ Snwt, hm.t-ntr $n$ 3s.t Nbt-hwwtprWsjr-Hp prWsjr m Rw.t-jswt prinpwtpjd $\underline{d} w=f$ hm.t-ntrn s3.t $n s w P j j l w t r 3) '$ '. Also, her statue has been found within the Sarapieion itself. ${ }^{44}$ Additionally, among all known female members of the priestly families at Memphis during the Ptolemaic era, her social status is still unprecedented: at present, Heresankh is the only known priestess of the temples within the Memphite necropolis. Her uppermost rank in the social hierarchy of Memphis must have been connected to her ancestry. All other known women in Memphis during the Ptolemaic period are usually only sistrum players of various divinities. For example, all known consorts of Ptolemaic high priests of Ptah were usually designated as sistrum players. ${ }^{45}$ Besides, the only other known perfect player of the sistrum of Min, the lord of Senut, ${ }^{46}$ is Berenice, the daughter of a priest Meryptah and his wife Arsinoe, who died probably sometimes between 141-132 BC after a life of 64 years, 8 months and 26 days. ${ }^{47}$ Also, according to the currently available sources, access to the highest offices within the sanctuaries at Saqqara and Abusir has been restricted only to the family of high priests of Ptah and their closest relatives. ${ }^{48}$ Therefore, both H. de Meulenaere and J. Quaegebeur were right when they presumed that Heresankh belongs to the same family as Nesisti-Pedubast, ${ }^{49}$ though for different reasons than those presented here.

\section{Who was Heresankh?}

Several scenarios were proposed for the identity of Heresankh. H. de Meulenaere initially proposed that Neferibre and Herankh, Heresankh's parents, ${ }^{50}$ were identical with

close examination of this break by the present author, it is highly plausible that the next sign should be Gardiner O6, 'mansion, temple, enclosure (hw.t)', while in abreak could have been written Gardiner D28, 'soul ( $k$ ')'. A new reading would therefore be Hwt-k3-Pth ('Enclosure of the ka of Ptah'), the name of themain cult centre at Memphis, but from the New Kingdomonwards also used to refer to the city itself (cf. Sandman Holmberg 1946: 214-215; Badawi 1948: 6-7).

${ }^{42}$ cf. Collombert 2008: 84-85.

${ }^{43} \mathrm{cf}$. Devauchelle 1998: 597-600.

${ }^{44}$ cf. PM III ${ }^{2}, 818$.

${ }^{45}$ This will be discussed elsewhere.

${ }^{46}$ For the epithet, see LGG III, 732.

${ }^{47}$ Panov 2017a: 378 n. 751.

${ }^{48}$ This will be discussed in detail elsewhere.

49 cf. De Meulenaere 1959: 245-246; Quaegebeur 1980: 60 n. 7; followed by Hölbl 2001: 103; Pfeiffer 2017.

${ }^{50}$ De Meulenaere 1959: 244. 
the like named parents of a priest Neferibre, dedicant of the stela Vienna $130 .{ }^{51}$ According to assumptions that Heresankh died in year 22 of Ptolemy II and was a predecessor of Nesisti-Pedubast in the cult of Philotera, she was placed in the generation of Nefer(ibre), the grand-father of Nesisti-Pedubast, ${ }^{52}$ who was therefore identified with Neferibre B of Vienna 130 (Fig. 1).

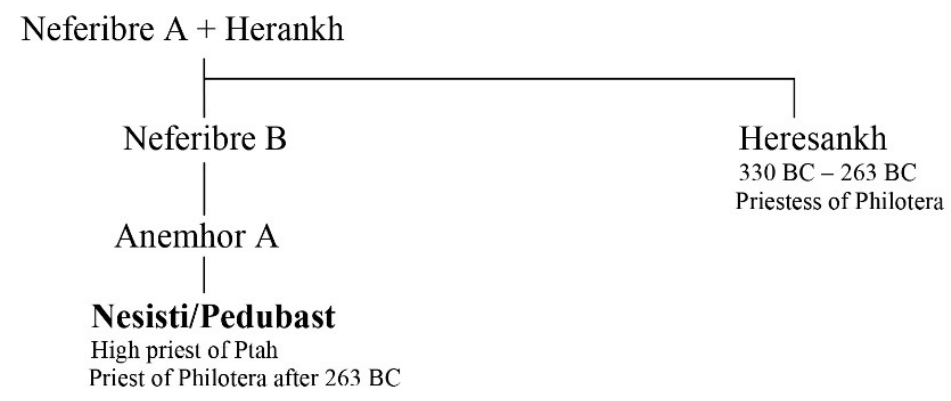

Fig. 1. The genealogy of Heresankh according to De Meulenaere

In that case, Heresankh would have been the great-aunt of Nesisti-Pedubast, who subsequently might have inherited her position in the cult of Philotera. This reconstruction is solely based on the dating of Vienna 130 to the early fourth century BC by $\mathrm{H}$. de Meulenaere. However, neither the dating of the stelae London BM EA 389 and Vienna 130, nor prosopographical information support this scenario. Since the stela London BM EA 389 is similar to the stela London BM EA 391 of high priest Horemakhet, as already mentioned above, the stela Vienna 130 shows striking similarities to another monument dedicated by a member of the family of high priests of Ptah, i.e. the so-called Saqqara stela of Nefertiti, the daughter of the same Horemakhet and his wife Nefersobek: instead of usual htp-dj-nsw formula on the beginning of the texts, both texts start with words of gods ( $d d m d w j n)$, while employment of hieroglyphic sign Gardiner W18 in noun $k b h w$, 'libation', instead of usual hieroglyphic sign Gardiner W15, and noun $m \underline{d} t$, 'ointment', before špst, 'ritual jar' is consistent. ${ }^{53}$ The $h t p-d j-n s w$ formula is also absent from the London stela of Horemakhet and the Bologna stela of Ahmose. On the other hand, P. Munro wrongly considered her as the daughter of high priest Anemhor II,${ }^{54}$ who was the father of high priest Horemakhet, assuming that Heresankhs of the London stela and the Louvre statue are two different women. ${ }^{55}$ This idea is repeated recently, when M. Panov concluded that "there is no obvious close connections between the statue Louvre N 2456 and the stela [London] BM [EA]

\footnotetext{
${ }^{51}$ Republished in Panov 2017a: 394-398 (with older literature).

52 cf. Kelley 1995: 35-36.

${ }^{53}$ Panov 2017a: 395. This has been already proposed by J. Quaegebeur (1974: 74-75).

${ }^{54}$ Munro 1973: 162.

${ }^{55}$ Coincidently, the mother of Horemakhet had the same name as the mother of Heresankh, Herankh (PP III 6041 = PP IX 6052a), who is prominently attested on monuments of her sons. Nevertheless, these two women cannot be identical for various reasons, although are chronologically close.
} 
389". ${ }^{56}$ Ultimately, it has been proposed that Heresankh could have been the daughter of another Neferibre, the son of high priest Nesisti-Pedubast, ${ }^{57}$ which shall be revisited below.

The identification of her father should be a starting point for possible solution. Although it is almost certain that the name Neferibre was somewhat common during this period, it should be noted that the total number of leading priestly families at Memphis during the Ptolemaicera was, although impossible to calculate, rather small and that most of the preserved monuments in fact belong to them. Also, each of their members tends to have been connected to one another in a certain way since most of them had worked in the same or complementary state institutions and temples or moved in the same circles. Finally, certain families strictly controlled specific priestly offices at Memphis for generations and tended to extend their power to other priestly sectors in and beyond the city itself in various ways, using massively heredity, marriage and nepotism, as well as to combine their religious positions with different administrative offices.

If Heresankh was living as early as year 22 of Ptolemy II, either her father Neferibre A or her probable brother Neferibre B can be identified with Nefer(ibre), the grandfather of high priest Nesisti-Pedubast.Nefer(ibre)is known from the stela Vienna 82, dated to year 5 of Ptolemy XII (77/76 BC) dedicated by his descendant high priest Pedubast II, ${ }^{58}$ and the statue Alexandria $27806,{ }^{59}$ probably depicting high priest Pedubast I identified here as the older son of Nesisti-Pedubast. ${ }^{60}$ On the stela Vienna 82, Nefer(ibre) is 'divine father, god's servant, master of the secrets of the house of Ptah, of Rosetjau, of the Sarapieion, of the

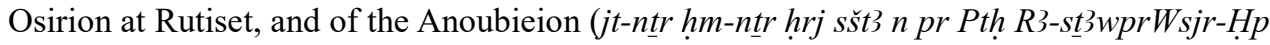
prWsjr $m$ Rw.t-jsw.t prinpw)', while on the statue Alexandria 27806, he is'divine father, beloved of god, master of the secrets in the house of Ptah and of Rutiset (jt-ntr mrj-ntr hrj sšt 3 n pr Pth Rw.t-jsw.t)'. Both set of titles are given to the same person, showing moderate differences in the titulary. His son Anemhor is designated as 'divine father, god's servant, master of the secrets of the house of Ptah, of Rosetjau, of the Sarapieion, of the Osirion at Rutiset, and of the Anoubieion, hereditary noble, prince, god's servant of Ptah, setem-priest

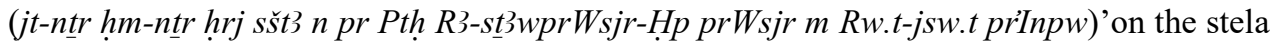
Vienna 82 and 'divine father, beloved of god, master of the secrets in the house of Ptah and of Rutiset (jt-ntr mrj-ntr hrj šst3 n pr Pth Rw.t-jsw.t)' on the statue Alexandria 27806. On both monuments, Nesisti(-Pedubast) is the first member of this family mentioned with the title of high priest. The titles of Nefer(ibre) roughly corresponds to the titles of Neferibre B and his father Neferibre A on the stela Vienna 130: the son is 'divine father, sem-priest, god's servant of Ptah, master of secrets of the house of Ptah and of Rosetjau (jt-ntr smhm-

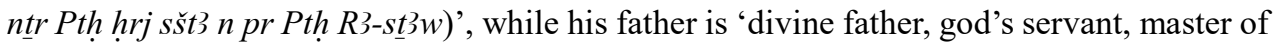
secrets of the Sarapieion, of the Osirion of Rutiset, and of the Anoubieion (jt-ntr htm-ntr hrj sšt 3 n prWsjr-Hp prWsjr Rw.t-jsw.t prinpw)'. In fact, when combined, they correspond closely to the full set of titles given on the stela Vienna 82 and the statue Alexandria 27806. This means that the like named individuals mentioned on the stelae Vienna 82 and 130 and

${ }^{56}$ Panov 2017b: 48.

${ }^{57}$ cf. Quaegebeur 1980: 60 n. 7.

${ }^{58}$ Republished in Panov 2017a: 167-174 (with older literature).

${ }^{59}$ Republished in Panov 2017a: 157-158 (with older literature).

${ }^{60}$ cf. Bakry 1972: 75; Devauchelle 1983: 135, 138; Panov 2017a: 157. 
the statue Alexandria 27806 respectively might be the one and the same. The main problem remains the dating of the stela Vienna 130. Earlier dating to the fourth century BC should be abandoned respecting already mentioned similarities to the Saqqara stela of Nefertiti, the daughter of high priest Horemakhet, who certainly died in the first half of the second century BC. Therefore, neither Neferibre A nor Neferibre B of Vienna 130 could be the same individual as Nefer(ibre), the grandfather of high priest Nesisti/Pedubast.

The connection between two families is Heresankh herself. As already mentioned above, the same sanctuaries in the Memphite areaspecified in the titularies of the people attested on the stela Vienna 130 are mentioned in the titulary of Heresankh on her Louvre statue, showing that she served as the only known priestess in the same temples as her father Neferibre A and the two ancestors of high priest Nesisti/Pedubast respectively, while a full brother-sister relationship for her and Neferibre B is beyond certain. The internal organization of a text on the stela Vienna 130 is also helpful here. More specifically, the line 6 contains the names of Anemhor and Neferibre, the same ones of the father and grandfather of Nesisti/Pedubast, both holding the same sequence of Memphite priestly titles: 'god's servant of Ptah, master of the secrets of the house of Ptah and of Rosetjau (hm-ntr Pth hrj sšt $n$ n pr Pth R3-st $\underline{3}$ w)'. This set of titles covers the responsibilities for both the temple of Ptah within the city of Memphis and the Memphite necropolis, which perfectly corresponds to the titularies of Neferibre and his son Anemhor on the stela Vienna 82 and the statue Alexandria 27806 respectively. Nevertheless, the position of these names in the text of Vienna 130 is problematic. Both names hold the last and the penultimate position in a line of seven individuals: Neferibre son $(s 3)$ of Neferibre born to Herankh $s 3$ Psamtekmen $s 3$ Peteharendjotef $s 3$ Anemhor $s 3$ Neferibre. This would usually be interpreted as a linear ascent as it was already suggested by D. H. Kelley, who proposes to see here a linear paternal line of priests of Ptah reaching the First Persian Period (Fig. 2), hence identifying Neferibre son of Neferibre as the grand-father of Nesisti-Pedubast, but in reality only following the identifications made by $\mathrm{H}$. de Meulenaere. ${ }^{61}$ However, the usual practice, when naming both parents and the ancestors of a father, was to name the father's ancestors before naming the mother. ${ }^{62}$ The problem was caused by the writing of the name of Neferibre's mother between the name of his father and other names. H. de Meulenaere suggested that this could be an error and that it should be written 'his son $(s 3=f)$ ' instead of only 'son $(s 3)$ ' before four individuals named after Herankh, citing examples from the Sarapieion, ${ }^{63}$ and transforming them into four sons of Neferibre B and not his ancestors. Additional argument for this proposal is the lineage of a priest Psamtekmen, attested on two undated statues Chicago $\mathrm{F}$ 31697 and Aquitaine 8636, ${ }^{64}$ where he is designated as the son of Neferibre and Heru. This Neferibre is therefore identified with Neferibre B, the brother of Heresankh.

\footnotetext{
${ }^{61}$ cf. Kelley 1995: 37.

${ }^{62}$ Already discussed by De Meulenaere 1959: 244-245.

${ }^{63}$ De Meulenaere 1959: 245 n. 1.

${ }^{64}$ Republished in Panov 2017a: 390-393 (with older literature).
} 


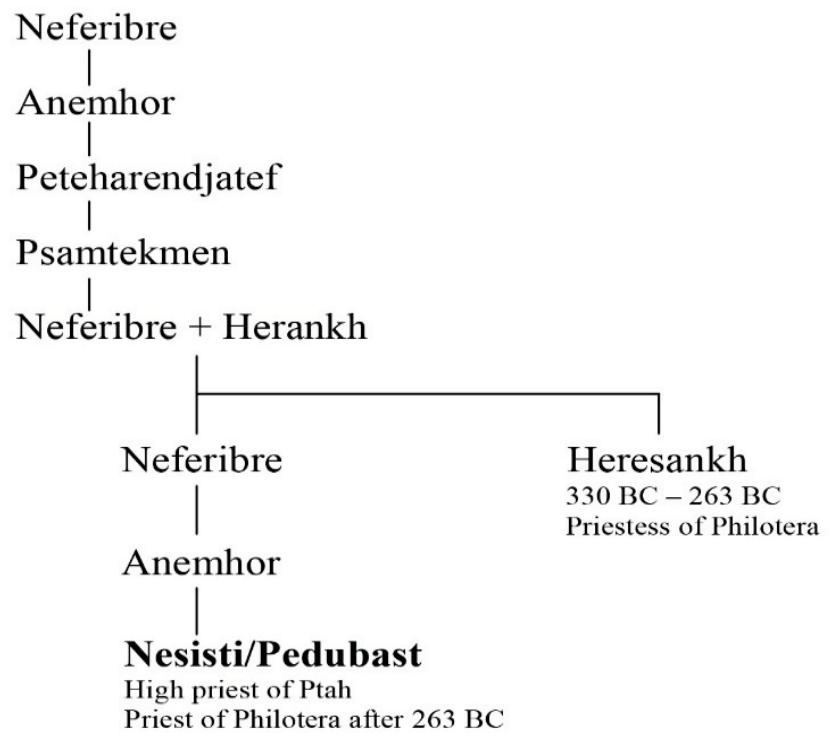

Fig. 2. The genealogy of Heresankh according to Kelley

Both of his arguments are unsustainable. In so far available non-royal stelae from the Sarapieion, ${ }^{65}$ if the names of the children of dedicant are mentioned, they are always followed by the name(s) of their mother(s), which is clearly lacking on the stela Vienna 130. Possible solution is to suppose that a scribe originally intended to name the ancestors of the dedicant's mother, meaning that $s 3$ of Psamtekmen is an error for $s 3<. t>$ of Psamtekmen. This has already been proposed by P. Munro. ${ }^{66}$ The feminine $-t$ is found also omitted on the already mentioned Saqqara stela of Nefertiti, which is securely dated to the early second century BC. ${ }^{67}$ If we add to these arguments that the funerary stela London BM EA 389 of Heresankh is similar to the funerary stela London BM EA 391 of high priest Horemakhet, the father of Nefertiti, it seems plausible that Heresankh and Neferibre were in fact contemporaries to high priest Horemakhet and his family. This only further speaks in favour of the death of Heresankh in year 22 of Ptolemy V, instead of Ptolemy II or Ptolemy III. As a result, Herankh, the mother of Heresankh, in fact belonged to the family of close relatives of high priests of Ptah, both lines having the joint ancestor in Anemhor, the father of high priest Nesisti-Pedubast (Fig 3.).

\footnotetext{
${ }^{65}$ For example, Louvre IM 4046 dated to year 34 of Darius I (Chassinat 1901: 84-85 cxlii), Louvre IM 4008 dated to year 34 of Darius (Chassinat 1899: 65-66 xxiii), Louvre IM 4072 dated to year 34 of Darius I (Chassinat 1899: 65 xxii) and others.

${ }^{66}$ Munro 1973: 342.

${ }^{67}$ cf. Panov 2017a: 195.
} 


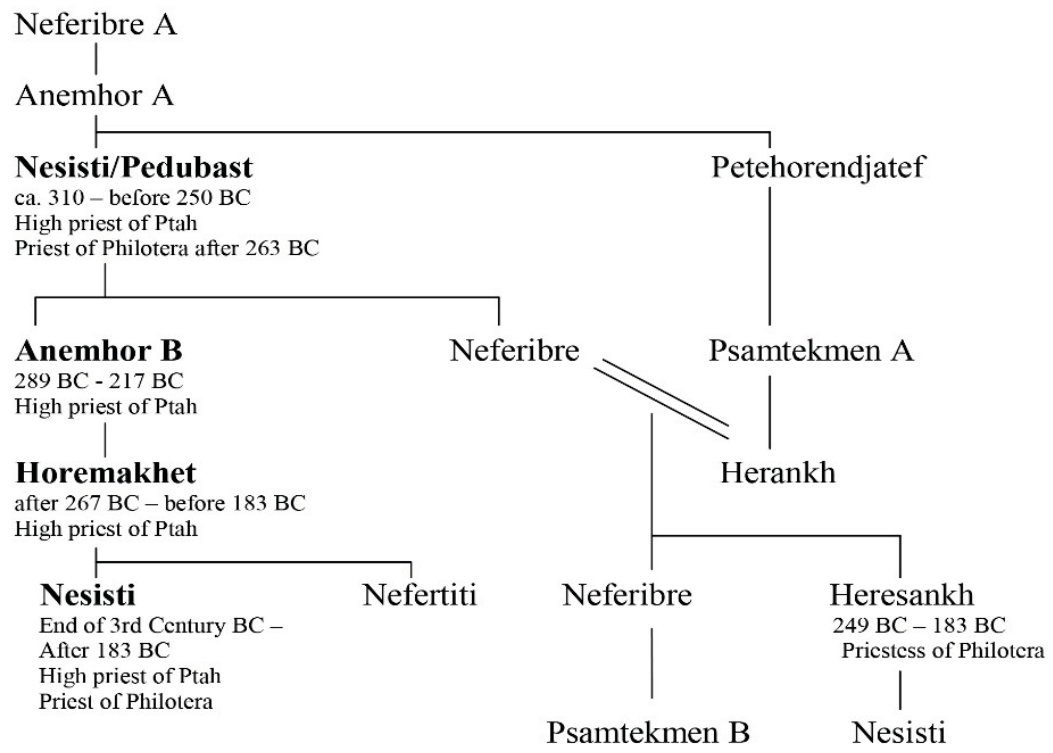

Fig. 3. The genealogy of Heresankh according to Marković

Additionally, the titles of Psamtekmen on the statues Chicago F 31697 and Aquitaine 8636 are slightly different from the titles mentioned for the like-named individual on the stela Vienna 130. Psamtekmen is 'divine father, beloved of the god, sem-priest, [god's] servant of Ptah, attendant of pleasant smell, one of big power, master of the secrets of the Osirion of Rutiset, god's servant of Khnum, foremost of his bird trap (jt-ntr mrj-ntr sm hm[$n t r]$ sdmndmstj wr b3w hrj sšt3 $n$ prWsjr Rw.t-jsw.t hm-ntr Hnm hntjw3rt=f) ${ }^{\prime 68}$ on both statues, while Psamtekmen of the stela Vienna 130 is 'divine father, god's servant, master of secrets of the Sarapieion, of the Osirion of Rutiset, and of the Anoubieion (jt-ntr $h m-n t r$ hrj sšt 3 n prWsjr-Hp prWsjr Rw.t-jsw.t prinpw)', like his probable father Peteharendjotef, but distinctive from his probable grand-father Anemhor and his probable great-grand-father Neferibre. If we accept that individuals on Vienna 130 are maternal ancestors of its dedicant, that means that Psamtekmen on the statues Chicago F 31697 and Aquitaine 8636 could have been a son of Neferibre B, the brother of Heresankh, himself being named after his maternal great-grandfather, again a usual practice in Memphis for centuries. ${ }^{69}$ If so, he should be designated as Psamtekmen B. His father is styled 'the like-titled $(m j-n n)$ ', meaning that he held all mentioned titles before them being transferred to his son. When we compare two sets of titles of Neferibre B of Vienna 130 and titles of the like-named individual on

\footnotetext{
${ }^{68}$ For the epithet, see LGG V, 795.

${ }^{69}$ The nice example is the stela Louvre IM 4097 dated to year 34 of Darius I (Chassinat 1901: 78-79 cxxxiii).
} 
Psamtekmen B's statues, they are again fully complementary.

Positions 'attendant of pleasant smell' and'one of big power' that are also missing from Vienna 130 are present on a papyrus Louvre N 3084 of Neferibre, son of high priest Nesisti-Pedubast and Nefersobek. ${ }^{70} \mathrm{He}$ is titled there 'god's father, attendant of pleasant smell, one of big power, god's servant'. ${ }^{71}$ That Neferibre of Chicago F 31697 + Aquitaine 8636 belonged to the family of high priests of Memphis imply the title of god's servant of Khnum, foremost of his bird trap. The only other two holders of this title are both named Anemhor, former being a high priest of Memphisthat lived between $289 \mathrm{BC}$ and $217 \mathrm{BC},{ }^{72}$ and later being the Letopolite priest that lived between $217 \mathrm{BC}$ and $132 \mathrm{BC}^{73}$ High priest Anemhor was the full brother of Neferibre attested on Louvre N 3084.It is already proposed that this Neferibre could have been the same as the father of Heresankh, ${ }^{74}$ which is a highly plausible scenario, since he is styled only as god's servant on her Louvre statue. In fact, when all titles are collected from all objects mentioning Neferibre (Table 1), all of his positions can be found already attested in the titulary of his brother, high priest Anemhor, attested on his funerary stela Vienna $153 .{ }^{75}$ This would also explain the name of Heresankh's son Nesisti of unknown father: he was named after his paternal great-grandfather, high priest NesistiPedubast. Close blood relation between two branches of the same family would therefore allow Heresankh to serve as a priestess of the most important Memphite sanctuaries and her birthdate around $249 \mathrm{BC}$ fully corresponds to the time when her paternal grandfather, high priest Nesisti-Pedubast, died. After his death, the position within the cult of Philotera was only transferred to his granddaughter.

\begin{tabular}{|c|c|c|c|c|c|c|c|c|c|c|}
\hline & $\begin{array}{l}J t- \\
n \underline{t} r\end{array}$ & $s m$ & $\begin{array}{l}h m- \\
n t r\end{array}$ & $\begin{array}{l}m r j \\
-n \underline{t} r\end{array}$ & $\begin{array}{c}\text { hrj sšt }{ }^{3} n \\
\text { prWsjr-Hp }\end{array}$ & $\begin{array}{l}\text { hrj sšt }{ }^{3} n \\
\text { prinpw }\end{array}$ & $\begin{array}{l}s \underline{d} m n \\
\underline{d} m s t j\end{array}$ & $\begin{array}{c}w r \\
b 3 w\end{array}$ & $\begin{array}{c}h r j s s^{\prime}{ }^{\prime} n \\
\text { prWsjr } \\
\text { Rw.t-jsw.t }\end{array}$ & $\begin{array}{c}\text { hm-ntr } \\
\text { Hnm } \\
\text { hntj } \\
w 3 r t=f\end{array}$ \\
\hline Vienna 130 & * & $*$ & $*$ & * & * & * & I & I & * & I \\
\hline $\begin{array}{c}\text { Chicago F } \\
31697+ \\
\text { Aquitaine } \\
8636 \\
\end{array}$ & $*$ & $*$ & $*$ & * & / & / & * & $*$ & $*$ & * \\
\hline $\begin{array}{c}\text { Louvre N } \\
3084\end{array}$ & $*$ & / & $*$ & / & / & / & $*$ & $*$ & I & / \\
\hline $\begin{array}{c}\text { Louvre N } \\
2456=\mathrm{IM} \\
6165\end{array}$ & / & / & $*$ & / & / & / & / & / & / & / \\
\hline
\end{tabular}

Table 1 Titles of Neferibre B

\footnotetext{
${ }^{70}$ PP III 5647.

${ }^{71}$ Panov 2017a: 129-130.

${ }^{72}$ PP III 5352 = PP III 5442. PP IX also equates him to PP IX 5442a.

73 cf. Panov 2014: 183-213.

${ }^{74}$ Quaegebeur 1971: 239, 246; Thompson 1988': 128.

${ }^{75}$ Republished in Panov 2017a: 132-135 (with older literature).
} 


\section{Conclusion}

According to this reconstruction, Heresankh was the daughter of Neferibre, who was the son of Nesisti-Pedubast, a high priest of Memphis appointed by Ptolemy II. On the other hand, her mother, Herankh, was the grand-daughter of the brother of the same NesistiPedubast, named Peteharendjatef, making this couple closely related: Neferibre married his first cousin's daughter. Heresankh also had a full brother, Neferibre B, who himself had a son named Psamtekmen B.Together with Heresankh's own son Nesisti, Psamtekmen B is the last known male member of this secondary branch. Heresankh herself lived very likely between $249 \mathrm{BC}$ and $183 \mathrm{BC}$. Her significance as an offspring of two lines of the same powerful priestly family lies in the fact that she is the only known priestess of the most important sanctuaries in the Memphite necropolis, namely the Sarapieion, the Osirion of Rutiset and the Anoubieion, all located at Saqqara and Abusir. No other woman is known to have attained such high social standing in Memphis during the Ptolemaic period until Taneferhor or her daughter were named "the great wife of Ptah ( $t 3$ hm.t $3 . t$ Pth)" in 44/43 BC. ${ }^{76}$

\section{REFERENCES:}

Abbreviations

LGG $=$ Leitz, Ch. Lexikon der ägyptischen Götter und Götterbezeichnungen, 8 vols, Leuven: Peeters, 2002-2003

PM III = Porter, B. and R. L. B. Moss, Topographical bibliography of ancient Egyptian hieroglyphic texts, reliefs, and paintings IV: Lower and Middle Egypt (Delta and Cairo to Asyûțt), Oxford: Clarendon, 1934.

PP III = Peremans, W., E. van'tDack, H. de Meulenaere, and J. Ijsewijn, Prosopographia Ptolemaica III: le clergé, le notarial, les tribunaux nos. 4984-8040, Leiden: E. Nauwelaerts; E. J. Brill, 1956.

PP IX = Clarysse, W. Prosopographia Ptolemaica IX: addenda et corrigenda au vol. III (1956), Lovanii: Almae Matri Lovaniensi, 1981.

Badawi, A. Memphis als zweite Landeshauptstadt im Neuen Reich. Le Caire: Imprimerie de l'Institut français d'archéologie orientale, 1948.

Bakry, H. S. K. 'A family of high-priests of Alexandria and Memphis', Mitteilungen des Deutschen Archäologischen Instituts Abteilung Kairo, 28, 1972, 75-77.

Carney, E. D. Arsinoë of Egypt and Macedon: a royal life, New York: Oxford University Press, 2013.

Chassinat, É. 'Textes provenant du Sérapéum de Memphis', Recueil de travaux relatifs à la philologie et à l'archéologie égyptiennes et assyriennes, 21, 1899, 56-73.

. 'Textes provenant du Sérapéum de Memphis (suite)', Recueil de travaux relatifs à la philologie et à l'archéologie égyptiennes et assyriennes, 23, 1901, 76-91.

Collombert, $\mathrm{Ph}$. 'La "stèle de Saïs" et l'instauration du culte d'Arsinoé II dans la chôra', Ancient Society, 38, 2008, 83-101.

\footnotetext{
${ }^{76}$ cf. Panov 2017a: 228-234 (with older literature)
} 
Devauchelle, D. 'Le titre du grand prêtre memphite', Revue d'égyptologie, 43, 1992, 205-207.

. 'Une invocation aux dieux du Sérapéum de Memphis', in: W. Clarysse, A. Schoors, and Harco Willems (eds.), Egyptian religion: the last thousand years. Studies dedicated to the memory of Jan Quaegebeur: part I, Leuven: Peeter, 1998, 589-611.

. 'Osiris, Apis, Serapis et les autres: remarques sur les Osiris Memphites au Ier millénaire av. J.-C.', in: L. Coulon (ed.), Le culte d'Osiris au ler millénaire av. J.-C.: découvertes et travaux récents. Actes de la table ronde internationale tenue à Lyon, Maison de l'Orient et de la Méditerranée (Université Lumière-Lyon 2) les 8 et 9 juillet 2005. Le Caire: Institut Français d'Archéologie Orientale, 2010, 49-62.

Gorre, G. Les relations du clergé Égyptien et des lagides d'après les sources privèes, Leuven: Peeters, 2009.

Grzybek, E. Du calendrier macédonien au calendrier ptolémaïque: problèmes de chronologie hellénistique, Basel: Friedrich Reinhardt, 1990.

Hölbl, G. A history of the Ptolemaic empire, translated by Tina Saavedra, London: Routledge, 2001.

Kelley, D. H. 'A Priestly Family of Memphis', Journal of Ancient and Medieval Studies 12, 1995, $25-39$.

Klotz, D. 'Regionally specific sacerdotal titles in Late Period Egypt: soubassements vs. private monuments', in: A. Rickert and B. Ventker (eds.), Altägyptische Enzyklopädien. Die Soubassements in den Tempeln der griechisch-römischen Zeit: Soubassementstudien I 2, Wiesbaden: Harrassowitz, 2014, 717-792.

Macurdy, G. H. Hellenistic queens: a study of woman power in Macedonia, Seleucid Syria, and Ptolemaic Egypt, Baltimore: Johns Hopkins Press, 1932.

Manning, J. G. Land and power in Ptolemaic Egypt: the structure of land tenure. Cambridge: Cambridge University Press, 2003.

Maystre, Ch. Les grands prêtres de Ptah de Memphis, Freiburg (Schweiz); Göttingen: Universitätsverlag; Vandenhoeck \& Ruprecht, 1992.

Meulenaere, H. de 'Prosopographica Ptolemaica', Chronique d'Égypte, 34 (68), 1959, 244-249.

Meulenaere, H. de 'Priester(tum) (SpZt)', in: W. Helck and W. Westendorf (eds.), Lexikon der Ägyptologie IV: Megiddo-Pyramiden, Wiesbaden: Harrassowitz, 1982, 1097-1098.

Munro, P. Die spätägyptischen Totenstelen, Glückstadt: Augustin, 1973.

Naville, É. 'La stèle de Pithom', Zeitschrift für ägyptische Sprache und Altertumskunde, 40, 1902, 66-75.

Oppen de Ruiter, B. F. van 'The death-date of Arsinoe II Philadelphus: the evidence reconsidered', Zeitschrift für Papyrologie und Epigraphik, 174, 2010, 139-150.

Otto, E. 'Eine memphitische Priesterfamilie des 2. Jh. v. Chr', Zeitschrift für ägyptische Sprache und Altertumskunde, 81, 1956, 109-129.

Panov, M. 'A family of Letopolite priests', Lingua Aegyptia, 22, 2014, 183-213.

Istochniki po istorii zhrecheskih semej Mamfisa i Letopolja v pozdnij period, 2 vols., Novosibirsk: M. V. Panov, 2017a. (Russian Cyrillic)

'A document relating to the cult of Arsinoe and Philotera', Journal of Egyptian History, 10 (1), 2017b, 43-49.

Pfeiffer, R. Kallimachosstudien. Untersuchungen zur Arsinoe und zu den Aitia des Kallimachos, München: M. Hueber, 1922.

Pfeiffer, S. Die Ptolemäer, Stuttgart: W. Kohlhammer, 2017.

Quaegebeur, J. 'Documents concerning a cult of Arsinoe Philadelphos at Memphis', Journal of Near Eastern Studies, 30 (4), 1971, 240-270. . 'Inventaire des stèles funéraires memphites d'époque ptolémaïque', Chronique d'Égypte, 49 (97), 1974, 59-79.

. 'The genealogy of the Memphite high priest family in the Hellenistic period',in: D. J. Crawford, J. Quaegebeur and W. Clarysse (eds.), Studies on Ptolemaic Memphis, Leuven: Peeters, 1980, 43-81. 
Sandman Holmberg, M. The god Ptah, Lund: Gleerup, 1946.

Thiers, Ch. 'Ptolémée Philadelphe et les prêtres de Saïs: la stèle Codex Ursinianus, fol.6 rf + Naples 1034 + Louvre C.123', Bulletin de l'Institut Français d'Archéologie Orientale 99, 1999, 423-445. . Ptolémée Philadelphe et les prêtres d'Atoum de Tjékou: nouvelle édition commentée de la "stèle de Pithom" (CGC 22183). Montpellier: Univ. Paul Valéry-Montpellier III, 2017.

Thompson, D. J. Memphis under the Ptolemies, Princeton, NJ: Princeton University Press, 1988. . Memphis under the Ptolemies, second ed., Princeton, NJ; Oxford: Princeton University Press, 2012.

Troy, L. Patterns of queenship in ancient Egyptian myth and history, Stockholm: Almqvist \&Wiksell International, 1986.

Vittmann, G. 'Rupture and continuity: on priests and officials in Egypt during the Persian period', in: P. Briant M. Chauveau (eds.), Organisation des pouvoirs et contacts culturels dans les pays de l'empire achéménide: actes du colloque organisé au Collège de France par la "Chaire d'Histoire et Civilisation du Monde Achéménide et de l'Empire d'Alexandre" et le "Réseau International d'Études et de Recherches Achéménides" (GDR 2538 CNRS), 9 - 10 novembre 2007, Paris: DeBoccard, 2009, 89-121.

\author{
НЕНАД МАРКОВИЋ \\ Карлов универзитет у Прагу \\ Чешки институт за египтологију

\section{ЗАНИМЉИВ СЛУЧАЈ ХЕРЕСАНХ, „САВРШЕНЕ СВИРАЧИЦЕ МИНОВОГ СИСТРУМА” И „СВЕШТЕНИЦЕ КРАЉЕВЕ СЕСТРЕ ФИЛОТЕРЕ”}

\begin{abstract}
Резиме
Рад настоји да разреши проблеме везане за идентификацију Хересанх, „савршене свирачице Миновог систрума” и „свештенице краљеве сестре Филотере”, и да предложи њен положај унутар бочне гране моћне породице врховних свештеника Мемфиса у време владавине династије Птоломеида. Истраживање указује да је она највероватније припадала бочној грани исте породице чије су обе линије имале заједничког претка у свештенику Анемхору, који је заправо био отац Несисти-Педубаста, првог Птаховог првосвештеника под хеленистичком династијом. Она је највероватније живела између 249. и 183. године пре нове ере. Брачна заједница њених родитеља, Неферибреа и Херанх, који су били у сродству морала је да утиче на њен друштвени положај у Мемфису будући да је Хересанх једина позната свештеница из најважнијих светилишта мемфиске некрополе - Серапеона, Озириона Рутисета и Анубиона, која се сва налазе у Сакари и Абусиру.
\end{abstract}

Кључне речи: Египат Птоломеја, домаће елите, Птахов првосвештеници, Мемфис, историја жена, свештенство. 